\title{
Possibilities in Identification of Genomic Species of Burkholderia cepacia Complex by PCR and RFLP
}

\author{
LUCIE NAVRÁTILOVÁ*, MAGDALENA CHROMÁ, VOJTǏCH HANULÍK and VLADISLAV RACLAVSKÝ \\ Department of Microbiology, Faculty of Medicine and Dentistry, Palacký University Olomouc, \\ 77515 Olomouc, Czech Republic
}

Submitted 5 February 2013, revised 11 May 2013, accepted 16 November 2013

\begin{abstract}
The strains belonging to Burkholderia cepacia complex are important opportunistic pathogens in immunocompromised patients and cause serious diseases. It is possible to obtain isolates from soil, water, plants and human samples. Taxonomy of this group is difficult. Burkholderia cepacia complex consists of seventeen genomic species and the genetic scheme is based on recA gene. Commonly, first five genomovars occurre in humans, mostly genomovars II and III, subdivision IIIA. Within this study we tested identification of first five genomovars by PCR with following melting analysis and RFLP. The experiments were targeted on eubacterial 16S rDNA and specific gene recA, which allowed identification of all five genomovars. RecA gene appeared as more suitable than $16 \mathrm{~S} \mathrm{rDNA}$, which enabled direct identification of only genomovars II and V; genomovars I, III and IV were similar within 16S rDNA sequence.
\end{abstract}

Ke y words: recA, 16S rDNA, HRMA

\section{Introduction}

Mapping and dissemination of infection agents are an important topic in public health and epidemiology. Molecular methods have contributed to recent advances in the tracking of the nosocomial and environmental spread of pathogenic bacteria. These methods enable genetic identification of microbes at the level of subspecific strains (Belkum et al., 2002).

Burkholderia cepacia complex (Bcc) is a very diverse group of bacteria, whose members are opportunistic human pathogens that can cause infections in immunocompromised patient, for example with cystic fibrosis and in other people with immune deficiency (Govan et al., 1996). Species from the Bcc can be transmitted between patients and are frequently resistant to wide range antibiotics. In addition, infection with these strains can cause a "cepacia syndrome" or a necrotizing pneumonia with bacteremia which leads to an acute and frequently fatal clinical decline (Frangolias et al., 1999; Isles et al., 1984). Distinction of genomic species in the Bcc by routine clinical microbiology methods is difficult. There are available phenotypic tests to identify genomovar II (species B. multivorans), genomovar IV (species B. stabilis) and genomovar V (species B. vietnamensis) (Whitby et al., 2000). From epidemiological point of view, it is important to distinguish genomovar II (species B. multivorans) and III (species B. cenocepacia) as infections caused by genomovar II can evolve into fatal "cepacia syndrome". The two above mentioned genomovars are more virulent than other belonging to complex. Identification of genomovars can be useful for treatment purposes (Zahariadis et al., 2003; Nash et al., 2011).

Aim of our study was to verify an applicability of the previously published systems for identification of genomovars belonging to the Bcc (Whitby et al., 2000; Mahenthiralingam etal., 2000 and Dřevínek etal., 2002). These systems use agarose gel electrophoresis as post-PCR analysis, however, we verified possibility of using melting analysis, which is closed system, so there is no possible cross contamination, reduced sample handling and the method is less time-consuming.

\section{Experimental}

\section{Materials and Methods}

Bacterial isolates. 145 clinical isolates from collection of Department of Microbiology, Faculty of Medicine and Dentistry, Palacký University Olomouc and Faculty Hospital Olomouc and 5 reference strains from

\footnotetext{
* Corresponding author: L. Navrátilová, Department of Microbiology, Faculty of Medicine and Dentistry, Palacký University Olomouc, 77515 Olomouc, Czech Republic; e-mail: L.Navratilova@atlas.cz
} 
The Belgium Coordinated Collections of Microorganism/Laboratorium Microbiologie Ghent (BCCM/LMG) LMG 1222, LMG 13010, LMG 16656, LMG 14294, LMG 10929 were used in this study. Strains were cultivated overnight on blood agar for DNA extraction.

DNA extraction. Chromosomal DNA was extracted from all strains by using heat extraction. First, colony was resuspended in $50 \mu \mathrm{l}$ of deionized water, incubated at $94^{\circ} \mathrm{C}$ for $10 \mathrm{~min}$, centrifuged by $13000 \times \mathrm{g}$ for $4 \mathrm{~min}$ and then $25 \mu$ l of supernatant was transferred into new tube. Extracted DNA was used directly as template for PCR or kept at $-20^{\circ} \mathrm{C}$ until needed.

PCR analysis. Each $20 \mu \mathrm{l}$ reaction contained $14.24 \mu \mathrm{l}$ deionized water, $2 \mu \mathrm{l}$ buffer complete (final concentration of $\mathrm{MgCl}_{2}$ was $1.5 \mathrm{mM}$ ), $1 \mu \mathrm{l}$ LCGreen Plus, $0.1 \mu \mathrm{l}$ of primer (final concentration $0.5 \mu \mathrm{M}$, primer pair to PCR system choose according Table I), $0.16 \mu 1$ dNTPs ( $25 \mathrm{mM}$ stock, final concentration $0.2 \mathrm{mM}$ ), 0.4 Taqpolymerase ( $2 \mathrm{U} /$ reaction) and $2 \mu \mathrm{l}$ DNA template. For real-time PCR amplification with following High-resolution melting analysis (HRMA) was performed using Rotor-Gene 6000 (Qiagen). Thermal cycling parameters for PCR system A and C included a pre-denaturation at $94^{\circ} \mathrm{C}$ for $7 \mathrm{~min}$ followed by 40 cycles of $30 \mathrm{sec}$ at $94^{\circ} \mathrm{C}$ (denaturation), $45 \mathrm{sec}$ at $62^{\circ} \mathrm{C}$ (annealing) and $60 \mathrm{sec}$ at $72^{\circ} \mathrm{C}$ (extension) and final extension $7 \mathrm{~min}$ at $72^{\circ} \mathrm{C}$ and melting in range from $55^{\circ} \mathrm{C}$ to $95^{\circ} \mathrm{C}$. Fluorescence data were acquired at $0.03^{\circ} \mathrm{C}$ increments.

Rotor-Gene software (version 2.0.2.4) enabled visualisation of HRM data. The negative derivative of fluorescence over temperature (df/dt) curve displays melting temperature $(\mathrm{Tm})$, the normalized curve represented the decreasing fluorescence versus increasing temperature (Wittwer et al., 2003). For distinguish of strains we used derivative curves with melting temperature (Tm).

Thermal cycling parameters for PCR system B included a pre-denaturation at $94^{\circ} \mathrm{C}$ for $7 \mathrm{~min}$ followed by 30 cycles of $45 \mathrm{sec}$ at $94^{\circ} \mathrm{C}$ (denaturation), $45 \mathrm{sec}$ at $66^{\circ} \mathrm{C}$ (annealing) and $120 \mathrm{sec}$ at $72^{\circ} \mathrm{C}$ (extension) and final extension $7 \mathrm{~min}$ at $72^{\circ} \mathrm{C}$.

Results from PCR system B were evaluated on the basis of negativity or positivity, according algorithm to identify genomovars of the Bcc, published earlier in Whitby et al. (2000).

For restriction fragment length polymorphism (RFLP) analysis, $10 \mu 1$ of PCR product amplified by PCR

Table I

Primers for PCR and RFLP used in experiments.

\begin{tabular}{|c|c|c|c|c|c|}
\hline $\begin{array}{c}\text { PCR } \\
\text { system }\end{array}$ & Specificity & $\begin{array}{c}\text { Primer } \\
\text { name }\end{array}$ & Primer sequence ( $5^{\prime}$ to $\left.3^{\prime}\right)$ & Target & Reference \\
\hline \multirow[t]{12}{*}{ A } & \multirow[t]{2}{*}{ Genomovar I (B. cepacia) } & BCRG11 & CAGGTCGTCTCCACGGGT & \multirow{12}{*}{ recA } & \multirow{12}{*}{$\begin{array}{l}\text { Mahenthiralingam } \\
\text { et al., 2000; } \\
\text { Dřevínek et al., } 2002\end{array}$} \\
\hline & & BCRG12 & CACGCCGATCTTCATACGA & & \\
\hline & \multirow[t]{2}{*}{ Genomovar II (B. multivorans) } & BCRBM1 & CGGCGTCAACGTGCCGGAT & & \\
\hline & & BCRBM2 & TCCATCGCCTCGGCTTCGT & & \\
\hline & \multirow[t]{2}{*}{ Genomovar IIIA (B. cenocepacia) } & BCRG3A1 & GCTCGACGTTCAATATGCC & & \\
\hline & & BCRG3A2 & TCGAGACGCACCGACGAG & & \\
\hline & \multirow[t]{2}{*}{ Genomovar IIIB (B. cenocepacia) } & BCRG3B1 & GCTGCAAGTCATCGCTGAA & & \\
\hline & & BCRG3B2 & TACGCCATCGGGCATGCT & & \\
\hline & \multirow[t]{2}{*}{ Genomovar IV (B. stabilis) } & BCRG41 & ACCGGCGAGCAGGCGCTT & & \\
\hline & & BCRG42 & ACGCCATCGGGCATGGCA & & \\
\hline & \multirow[t]{2}{*}{ Genomovar V (B. vietnamensis) } & BCRBV1 & GGGCGACGGCGACGTGAA & & \\
\hline & & BCRBV2 & TCGGCCTTCGGCACCAGT & & \\
\hline \multirow[t]{4}{*}{ B } & $\begin{array}{l}\text { Genomovar I } \\
\text { Genomovar III }\end{array}$ & G1 & GCCATGGATACTCCAAAAGGA & $23 \mathrm{~S}$ rDNA & \multirow{4}{*}{ Whitby et al., 2000} \\
\hline & Genomovar IV & G2 & TCGGAATCCTGCTGAGAGGC & \multirow{3}{*}{$16 \mathrm{~S}$ rDNA } & \\
\hline & $\begin{array}{l}\text { Genomovar I } \\
\text { Genomovar II } \\
\text { Genomovar III }\end{array}$ & SPR3 & TCGAAAGAGAACCGGCG & & \\
\hline & $\begin{array}{l}\text { Genomovar I } \\
\text { Genomovar IV }\end{array}$ & SPR4 & TCGAAAGAGAACCGATA & & \\
\hline \multirow[t]{4}{*}{$\mathrm{C}$} & \multirow[t]{2}{*}{ Universal } & UNI2 & GACTCCTACGGGAGGCAGCAG & \multirow{2}{*}{$16 \mathrm{~S}$ rDNA } & \multirow{4}{*}{$\begin{array}{l}\text { Mahenthiralingam } \\
\text { et al., } 2000\end{array}$} \\
\hline & & UNI5 & CTGATCCGCGATTACTAGCGATTC & & \\
\hline & \multirow[t]{2}{*}{ B. cepacia complex } & BCR1 & TGACCGCCGAGAAGAGCAA & \multirow{2}{*}{$r e c A$} & \\
\hline & & BCR2 & CTCTTCTTCGTCCATCGCCTC & & \\
\hline
\end{tabular}


system $\mathrm{C}$ was combined with deionized water $(17 \mu \mathrm{l})$, the appropriate restriction enzyme buffer $(2 \mu l)$ and endonuclease HaeIII $(1 \mu \mathrm{l})$ and incubated at $37^{\circ} \mathrm{C}$ for $7 \mathrm{~min}$. RFLP products were analysed by agarose gel electrophoresis, with agarose concentration 2\%. Molecular size marker of the appropriate size range was included on all gels (100 bp DNA ladder or 50 bp DNA ladder).

\section{Results}

We tested the utility of PCR and RFLP to distinguish first five genomovars of Bcc. These methods were tested on 145 clinical isolates and five reference strains from BCCM/LMG. Only one clinical isolate belonged to genomovar I, 109 clinical isolates to genomovar II and 35 to genomovar III, subdivision IIIA.

Genomovar specific amplification (PCR system A), Bcc specific PCR, which was aimed on recA gene, provided higher resolution capability. This method enables to distinguish all five tested genomovars and within genomovar III it was possible differentiate two subdivisions IIIA and IIIB. The identification by the PCR system A was based on the presence of the specific peak (Fig. 1). Results from melting analysis were supported with results from agarose gel electrophoresis, for verify usability of melting analysis for determination positive or negative reaction.

The system published by Whitby et al. (2000) (PCR system B) targeted 16S/23S rDNA within two PCR with primer pairs G1-G2 and SPR3-G1 or SPR4-G1. Primer pairs G1-G2 enabled to distinguish genomovars I, III and IV from genomovars II and V. Second PCR with primer pair SPR3-G1 or SPR4-G1 allowed identification of genomovars I/III, I/IV, II and V. It was possible to distinguish genomovars II and $\mathrm{V}$ according the PCR system B.

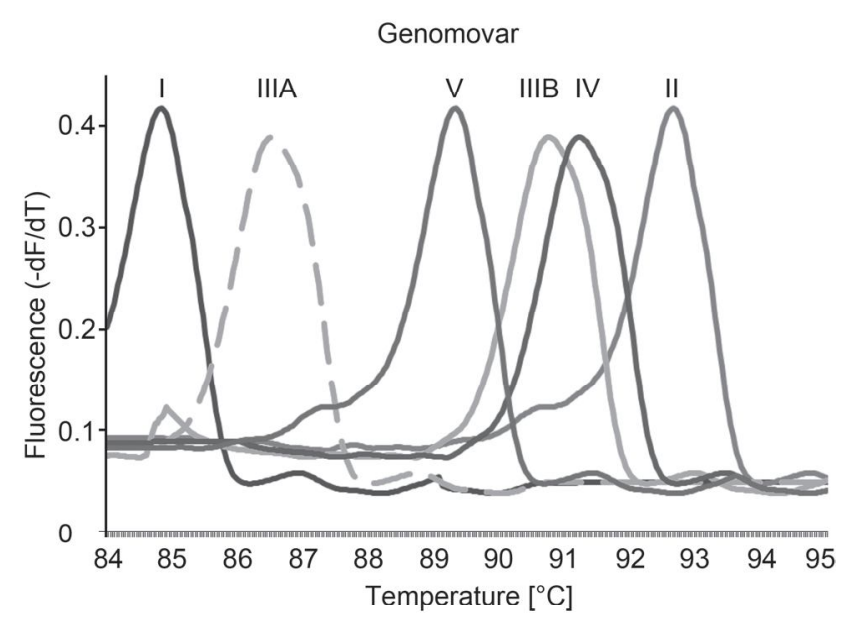

Fig. 1. Results of genomovar specific PCR-HRMA of five genomovars from Burkholderia cepacia complex.

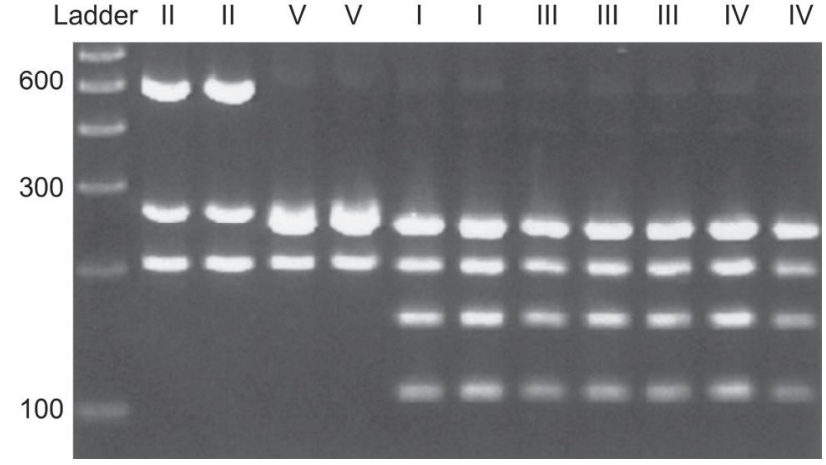

Fig. 2. RFLP analysis with HaeIII of $16 \mathrm{~S}$ rDNA of five genomovars from Burkholderia cepacia complex.

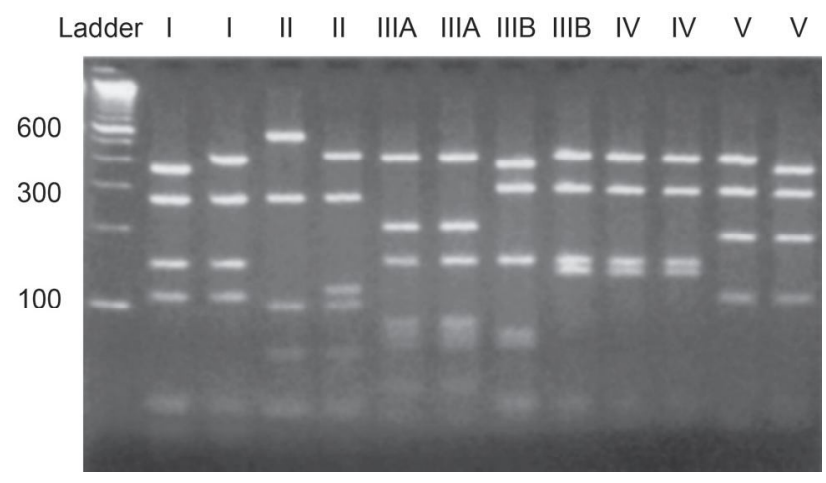

Fig. 3. RFLP analysis with HaeIII of recA gene of five genomovars from Burkholderia cepacia complex.

PCR system C with following RFLP analysis with HaeIII of PCR-amplicons of $16 \mathrm{~S}$ rDNA revealed sequence polymorphism capable of identifying genomovars II and V but was insufficient to discriminate genomovars I, III and IV (Fig. 2). RFLP analysis with HaeIII of PCR-amplicons of recA gene was enough sufficient nucleotide sequence variation to distinction of all tested genomovars I, II, III, IV and V (Fig. 3). Isolates of genomovar III included two the subdivision IIIA and IIIB after cleavage recA by HaeIII.

At first we demonstrated that the melting analysis can replace agarose gel electrophoresis as post-PCR analysis. Analysis of $r e c A$ gene by the PCR system A with following melting analysis or RFLP achieved the same discrimination power, and analysis of $16 \mathrm{~S}$ rDNA by the PCR system B with following melting analysis or RFLP gave the same results. The differentiation of genomovar II (species B. multivorans) was possible by using the PCR system $\Lambda, B$ or RFLP aiming $16 S$ rDNA and recA genes. Genomovar III (species B. cenocepacia) was directly identified only by genomovar specific PCR (PCR system A) or RFLP with HaeIII aimed at recA gene. Finally, we proved that the analysis of specific gene is more suitable for identification and distinction of Bcc than eubacterial gene, which we can find by all bacterial species. 


\section{Discussion}

Several studies have indicated problems with right identification of Bcc by phenotypic methods. The molecular methods are more reliable in this field (Henry et al., 1997; McMenamin et al., 2000). Within the genetic identification we aim for molecular marker recA gene and $16 \mathrm{~S} \mathrm{rDNA}$, which is very extensive for high degree of conservation and included variable regions (Liu et al., 2012).

Our results of PCR with following melting analysis or RFLP analysis were same as in studies Whitby et al., 2000; Mahenthiralingam et al., 2000a; McDowell et al., 2001 and Mahenthiralingam et al., 2002. Studies Mahenthiralingam et al. (2000b) and Dřevínek et al. (2002) describing the development of genomovar specific PCR. We tested their conclusions in practice and we compared it with PCR and RFLP aimed at eubacterial $16 S$ rDNA. Genomovar specific PCR and RFLP focused on $r e c A$ gene had better discriminating power.

We had not enough isolates of genomovar IIIB and IV (they are not easy accessible) so we cannot surely conclude that according results from melting analysis that the distinction of curves appertain to genomovar IIIB and IV is significant. We recommend verifying the results of identification of genomovars by agarose gel electrophoresis, size of PCR product is different, for IIIB is $781 \mathrm{bp}$ and for IV is $647 \mathrm{bp}$.

Whitby etal. (2000) developed PCR reactions focused on 16S rDNA and 23S rDNA for identification of Bcc. PCR was scored based on positive and negative reactions, described method enabled to distinguish genomovars II and $\mathrm{V}$, which had differences in sequence of $16 \mathrm{~S}$ rDNA and it was possible to suggest primers for dissimilar regions. Sequences of genomovar I was similar to genomovar II and IV.

We focused our experiments only on first five genomovars, which occur with the highest frequency. Their identification and discrimination would be beneficial as it includes two genetic types also that cause most complications in infected (occurrence of antibiotic resistance, cepacia syndrome). These are genomovar II and genomovar III and they are two the most commonly isolated genomovars too. These two genomovars are significant for epidemiology (Mahenthiralingam et al., 2002 and Jones et al., 2003).

\section{Acknowledgments}

This work was supported by Ministry of Health (grant LF_2012 006 and grant 521100571) Czech Republic.

\section{Literature}

Dřevínek P., H. Hrbáčová, O. Cinek, J. Bartošová, O. Nyč, A. Nemec and P. Pohunek. 2002. Direct PCR detection of Burkholderia cepacia complex and identification of its genomovars by using sputum as source of DNA. J. Clin. Microbiol. 40: 3485-3488.
Frangolias D.D., E. Mahenthiralingam, S. Rae, J.M. Raboud, A.G.F. Davidson, R. Wittman and P.G. Wilcox. 1999. Burkholderia cepacia in cystic fibrosis: variable disease course. Am. J. Respir. Crit. Care. Med. 160: 1572-1577.

Govan J.R.W. V.P. and Deretic. 1996. Microbial pathogenesis in cystic fibrosis: mucoid Pseudomonas aeruginosa and Burkholderia cepacia. Microbiol. Rev. 60: 539-574.

Henry D.A., M.E. Campbell, J.J. LiPuma J.J. and D.P. Speert. 1997. Identification of Burkholderia cepacia isolates from patients with cystic fibrosis and use of a simple nex selective medium. J. Clin. Microbiol. 35: 614-619.

Henry D.A., E. Mahenthiralingam, P. Vandamme, T. Coenye and D.P. Speert. 2001. Phenotypic methods for determining genomovar statut of the Burkholderia cepacia complex. J. Clin. Microbiol. 39: 1073-1078.

Isles A., I. Macluskey, M. Corey, R. Gold, C. Prober, P. Fleming and H. Levison. 1984. Pseudomonas cepacia infection in cystic fibrosis: an emerging problem. J. Pediatr. 104: 206-210.

Jones A.M., M.E. Dodd, J.R.W. Govan, V. Barcus, C.J. Doherty, J. Morris and A.K. Webb. 2004. Burkholderia cenocepacia and Burkholderia multivorans: influence on survival in cystic fibrosis. Thorax 59: 948-951.

Liu W., L. Li, M. Asaduzzaman and F. Zhu. 2012. Popular molecular markers in bacteria. Mol. Gen. Microbiol. Virusol. 27: 103-107. Mahenthiralingam E., A. Baldwin and P. Vandamme. 2002. Burkholderia cepacia complex infection in patients with cystic fibrosis. J. Med. Microbiol. 51: 533-538.

Mahenthiralingam E., J. Bischof, S.K. Byrne, C. Radomski, J.E. Davies, Y. AV-Gay and P. Vandamme. 2000b. DNA-based diagnostic approaches for identification of Burkholderia cepacia complex, Burkholderia vietnamensis, Burkholderia multivorans, Burkholderia stabilis and Burkholderia cepacia genomovar I and III. J. Clin. Microbiol. 38: 3165-3173.

Mahenthiralingam E., T. Coenye, J.W. Chung, D.P. Speert, J.R.W. Govan, P. Taylor and P. Vandamme. 2000a. Diagnostically and experimentally useful panel of strains from the Burkholderia cepacia complex. J. Clin. Microbiol. 38: 910-913.

McDowell A., E. Mahenthiralingam, J.E. Moore, K.E. Dunbar, A.K. Webb, M.E. Dodd, S.L. Martin, B.C. Millar, C.J. Scott, M. Crowe and J.S. Elborn. 2001. PCR-based detection and identification of Burkholderia cepacia complex pathogens in sputum from cystic fibrosis patients. J. Clin. Microbiol. 39: 4247-4255.

McMenamin J.D., T.M. Zaccone, T. Coenye, P. Vandamme and J.J. LiPuma. 2000. Misidentification of Burkholderia cepacia in US cystic fibrosis treatment centers - an analysis of 1,051 recent sputum isolates. Chest. 117: 1661-1665.

Valnaere E., J.J. LiPuma, A. Baldwin, D. Henry, E. De Brandt, E. Mahenthiralingam, D. Speert, C. Dowson and P. Vandamme. 2008. Burkholderia latens sp. nov., Burkholderia diffusa sp. nov., Burkholderia arboris sp. nov., Burkholderia seminalis sp. nov. and Burkholderia metallica sp. nov., novel species within the Burkholderia cepacia complex. Int. J. Syst. Evol. Microbiol. 58: 1580-1590.

Van Belkum A. 2003. High-throughput epidemiologic typing in clinical microbiology. Clin. Microbiol. Infect. 9: 86-100.

Vonberg R.P., S. Häußler, P. Vandamme and I. Steinmetz. 2006. Identification of Burkholderia cepacia complex pathogens by rapidcycle PCR with fluorescent hybridization probes. J. Med. Microbiol. 55: 721-727.

Whitby P.W., K.B. Carter, K.L. Hatter, J.J. LiPuma and T.L. Stull. 2000. Identification of members of the Burkholderia cepacia complex by species-specific PCR. J. Clin. Microbiol. 38: 2962-2965.

Zahariadis G., M.H. Levy and J.L. Burns. 2003. Cepacia-like syndrome caused by Burkholderia multivorans. Can. J. Infect. Dis. 14: $123-125$. 